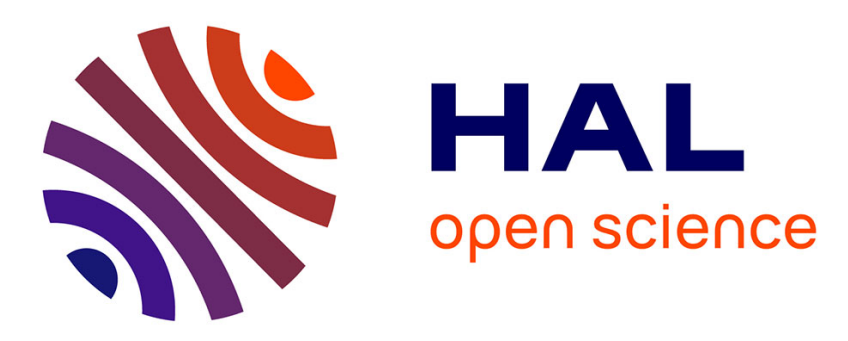

\title{
Synthesis, photophysical, thermal properties and X-Ray studies of novel organic dyes bearing Inden-1-ylidene and fluorene
}

\author{
M. Yahya, D. Çakmaz, Sylvain Achelle, E. Le Gall, E. Şahin, Z. Seferoğlu
}

\section{To cite this version:}

M. Yahya, D. Çakmaz, Sylvain Achelle, E. Le Gall, E. Şahin, et al.. Synthesis, photophysical, thermal properties and X-Ray studies of novel organic dyes bearing Inden-1-ylidene and fluorene. Journal of Photochemistry and Photobiology A: Chemistry, 2021, 416, pp.113311. 10.1016/j.jphotochem.2021.113311 . hal-03249696

\section{HAL Id: hal-03249696 https://hal.science/hal-03249696}

Submitted on 11 Jun 2021

HAL is a multi-disciplinary open access archive for the deposit and dissemination of scientific research documents, whether they are published or not. The documents may come from teaching and research institutions in France or abroad, or from public or private research centers.
L'archive ouverte pluridisciplinaire HAL, est destinée au dépôt et à la diffusion de documents scientifiques de niveau recherche, publiés ou non, émanant des établissements d'enseignement et de recherche français ou étrangers, des laboratoires publics ou privés. 


\section{Synthesis, Photophysical, Thermal Properties and X-Ray Studies of Novel}

\section{Organic Dyes bearing Inden-1-ylidene and Fluorene}

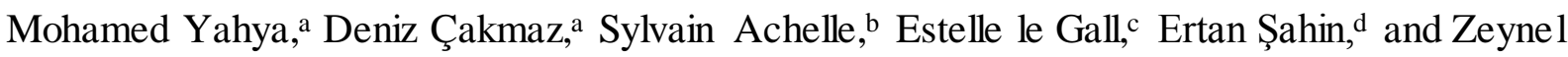
Seferoğlu $\mathrm{a}^{*}$

aDepartment of Chemistry, Faculty of Science, Gazi University, Yenimahalle, Ankara 06560, Turkey.

${ }^{b}$ Univ. Rennes, CNRS, Institut des Sciences Chimiques de Rennes-UMR6226, F 35000 Rennes,

France.

'IUT de Lannion, Université de Rennes 1, Rue E Branly, BP 30219, F 22302 Lannion, France

dDepartment of Chemistry, Atatürk University, Erzurum 25240, Turkey

*Corresponding author's Tel.: +90 312 2021525; fax: +90 3122122279

*E-mail addresses : znseferoglu@gazi.edu.tr (Z. Seferoğlu). 


\section{Graphical Abstract}

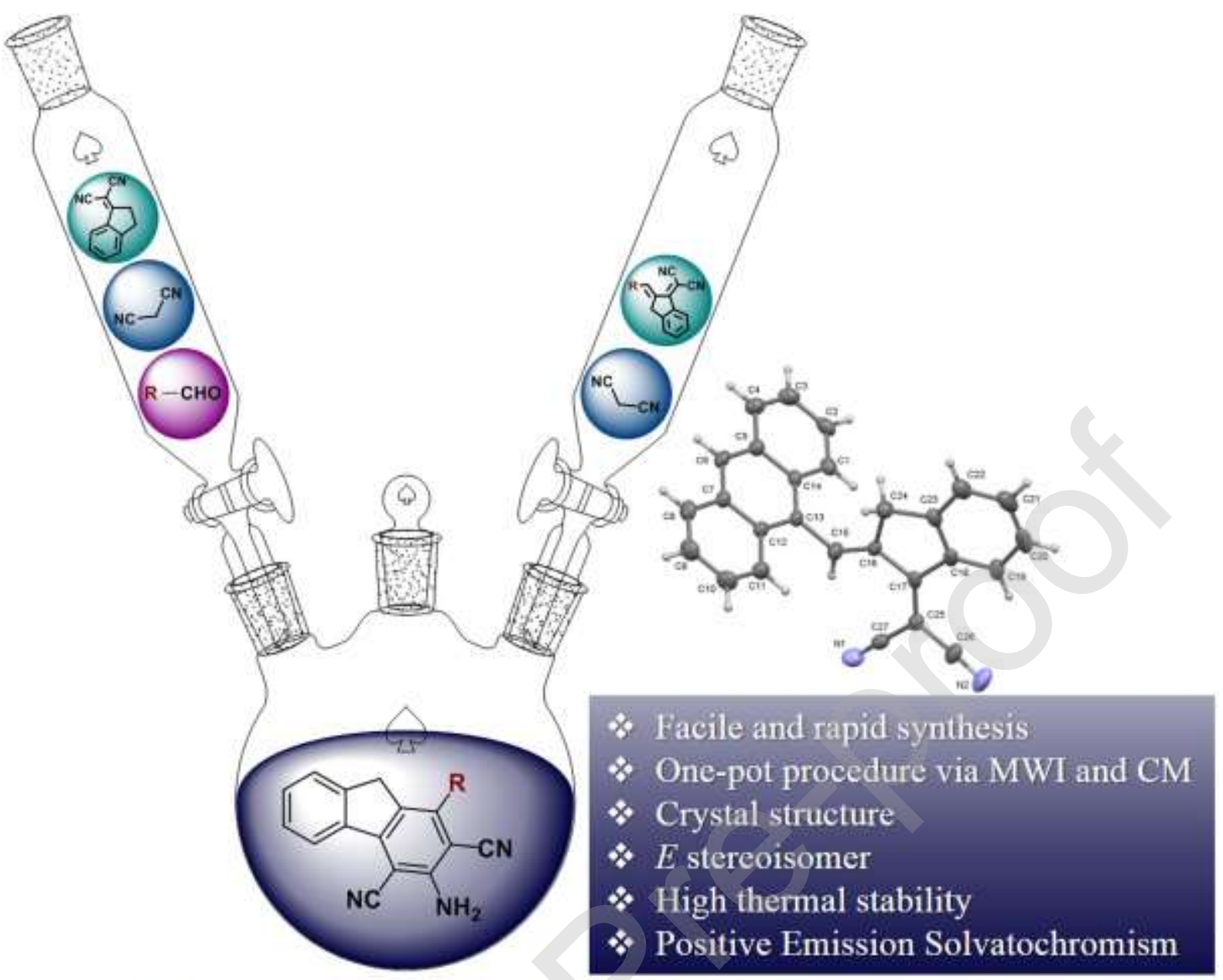

R: Phenyl, Anthracen-9-yl, Pyren-1-yl

\section{Highlights}

- A novel series of 3-Amino-1-phenyl/antranyl/pyrenyl-2,4-dicyanofluorene derivatives were synthesized.

- Fluorene-antrasen and fluorene-pyrene hybrids system will be present firstly in this manuscript.

- Conventional and microwave irradiation methods were compared to obtain better methods and high yields.

- Di/three-components one-pot method was used to synthesis the compounds.

- Photophysical and thermal properties of the compounds were investigated.

\section{Abstract}


Organic conjugated compounds containing various substituents 3-amino-2,4-dicyano-1-aryl$9 H$-fluorene and 1-dicyanomethylene-2-aryl-indone derivatives were successfully obtained. Various routes and synthesis methods, such as one-pot, multi-step, and microwave irradiation (MWI), were explored for efficiency. Spectroscopic methods were used to characterize the synthesized compounds. Furthermore (E)-2-(2-(anthracen-9-ylmethyle ne)-2,3-dihydro-1Hinden-1-ylidene) malononitrile (2b) compound which exhibited a crystal structure was characterized via X-ray technique. The thermogravimetric analysis (TGA) was used to investigate the thermal stability. Finally, the photophysical properties of the synthesized compounds were also investigated using UV-vis and fluorescence.

Keywords: Fluorene derivatives, Microwave irradiation, Thermogravimetric analysis, UV-vis, Fluorescence

\section{Introduction}

In the last decades, organic conjugated molecules have drawn significant interest due to several prospective optoelectronic applications. Organic materials offer several prospective and different benefits compared to their inorganic equivalents, such as good flexibility, better transparency, and lighter weight. Optoelectronic devices based on organic materials can be built onto an adjustable substrate to generate flexible electronic tools [1-4]. Organic light-emitting diodes (OLEDs) [5,6] and organic photovoltaic (OPV) [7-9] have thus attracted considerable interest. OLEDs are highly promising flat panel technologies that can generate large-area displays and solid-state illumination systems. Furthermore, OPV devices are a promising alternative solution for acquiring clean, renewable energy. 
The design of such organic molecules is driven by the aim of enhancing the performance of the devices via molecular structure adjustment. In this context, fluorene, pyrene, and anthracene fragments are particularly interesting.

Fluorene-based molecules have been extensively studied and found applications in electronic devices, medical fields, and optics [10-14]. The fluorene core is indeed an excellent $\pi$ conjugated core due to the planarization of the biphenyl unit [15-18]. The fluorene group is also electro-rich that can enhance the absorption properties and decrease the oxidation potential of materials. Additionally, the bulky fluorene fragment can restrains aggregation and excimer formation $[19,20]$.

Moreover, pyrene and anthracene belong to the polycyclic aromatic hydrocarbons family, and are known to act as an electron donor and electron acceptor. Pyrene displays intense photoluminescence (PL) in solution [21,22]. Usually, in condensed media, pyrene and its derivatives have a tendency to produce excimers [23,24]. On the other hand, anthracene derivatives have attracted many researchers due to their exceptional PL and electroluminescence (EL) properties, wide-energy gap, and good thermal stability, making these derivatives appealing as blue-emitting materials in OLEDs [25-27].

Numerous studies have tackled the advantages of combining pyrene or anthracene and fluorene groups into one chromophore [14, 28-31]. In this contribution, we designed two series of 1-dicyanomethylene-2-aryl-indones 2 and 3-amino-2,4-dicyano-1-aryl-9H-fluorene 3 (Chart 1) obtained by di/three-component one-pot method. Phenyl, anthracen-9-yl, and pyren-1-yl groups were used as aromatic fragments to enhance the PL properties. The photophysical of these compounds were studied in various media. 


\section{Expe rimental part}

\subsection{Materials and instrumentation}

The chemicals used in the synthesis of all compounds were obtained from Aldrich Chemical Company (USA) and were used without further purification. Compound 1 was obtained according to reported procedure [32]. All solvents used were of analytical grade. All reactions were magnetically stirred and monitored by thin-layer chromatography (TLC) using Merck silica gel $\left(60 \mathrm{~F}_{254}\right)$ plates $(0.25 \mathrm{~mm})$ and visualized with Ultraviolet light. FT-IR (ATR) spectra were recorded on Jasco FTIR 6800Q spectrometer (Sanko Tekstil Işletmeleri Sanayi ve Ticaret A. S. Isko Sb, Bursa, Turkey). ${ }^{1} \mathrm{H}$ NMR and ${ }^{13} \mathrm{C}$ spectra were recorded on Bruker ASCEND $600\left({ }^{1} \mathrm{H}: 600 \mathrm{MHz},{ }^{13} \mathrm{C}: 151 \mathrm{MHz}\right)$ spectrometer (Sanko Tekstil Işletmeleri Sanayi ve Ticaret A. S. Isko Sb, Bursa, Turkey) and Bruker Avance 300 ( ${ }^{1} \mathrm{H}$ NMR: $\left.300 \mathrm{MHz}\right)$ spectrometer (Gazi University Department of Chemistry, Turkey) in DMSO- $d_{6}$ and $\mathrm{CDCl}_{3}$. Chemical shifts are expressed in $\delta$ units (ppm) with tetramethylsilane (TMS) as the internal reference. Coupling constants $(J)$ are given in hertz $(\mathrm{Hz})$. Signals are abbreviated as follows: singlet, s; doublet, d; doublet-doublet, dd; triplet, t; multiplet, $\mathrm{m}$. All melting points are uncorrected and in degrees Celsius $\left({ }^{\circ} \mathrm{C}\right)$ (Electrothermal 9200 melting point apparatus). High-resolution mass spectra (HRMS) were recorded at Gazi University, Faculty of Pharmacy, Turkey using electron ionization (EI) mass spectrometry Waters-LCT-Premier-XE-LTOF (TOF-MS) instruments in $\mathrm{m} / \mathrm{z}$ (rel. \%). The microwave syntheses were carried out in Milestone Start microwave reaction system. Thermal analysis was performed with Shimadzu DTG-60H system, up to $600{ }^{\circ} \mathrm{C}(10$ $\left.{ }^{\circ} \mathrm{C} \min ^{-1}\right)$ under dynamic nitrogenatmosphere $\left(15 \mathrm{~mL} \mathrm{~min}^{-1}\right)$. Absorption and Photoluminescence spectra were recorded on a Spex Fluoromax-3 Jobin-Yvon Horiba 
spectrophotometer (at IUT Lannion, University of Rennes 1, France). Compounds were excited at their absorption maxima (band of lowest energy) to record the emission spectra. Fluorescence quantum yields $( \pm 10 \%$ ) were determined relative to 9,10 -bis(phenylethynyl)anthracene in cyclohexane $\left(\Phi_{F}=1.00\right)$ according to known procedure [33].

\subsection{X-ray Diffraction Analysis}

For the crystal structure determination, a single-crystal of the compound $2 \mathrm{a}$ was used for the data collection on a four-circle Rigaku R-AXIS RAPID-S diffractometer (equipped with a twodimensional area IP detector). Graphite-monochromated Mo-K $\alpha$ radiation $(\lambda=0.71073 \AA)$ and oscillation scans technique with $\Delta \mathrm{w}=5^{\circ}$ for one image were used for data collection. The lattice parameters were determined by the least-squares methods based on all reflections with $\mathrm{F} 2>2 \sigma(\mathrm{F} 2)$. Integration of the intensities, correction for Lorentz and polarization effects, and cell refinement were performed using CrystalClear (Rigaku/MSC Inc., 2005) software. The structure was solved by direct methods using SHELXS-97, and non-hydrogen atoms were refined using anisotropic displacement parameters by a full-matrix least-squares procedure using the program SHELXL-97. $\mathrm{H}$ atoms were positioned geometrically and refined using a riding model. The final difference Fourier maps showed no peaks of chemical significance. Crystal data for $\mathrm{x}$ : C16H20O8Br2, crystal system, space group: monoclinic, P21/n; (no:14); unit cell dimensions: $\mathrm{a}=9.4760(2), \mathrm{b}=15.7020(4), \mathrm{c}=12.9350(3) \AA, \alpha=90, \beta=91.61(2), \gamma=$ 90'; volume; 1923.87(8) $\AA 3, \mathrm{Z}=4$; calculated density: $1.272 \mathrm{~g} / \mathrm{cm}^{3}$; absorption coefficient: $0.075 \mathrm{~mm}-1 ; \mathrm{F}(000)$ : $768 ; \theta$-range for data collection $2.9-25.2^{\circ}$; refinement method: full-matrix least-squares on F2; data/parameters: 3100/263; goodness-of-fit on F2: 0.98; final R-indices [I $>2 \sigma(\mathrm{I})]: \mathrm{R} 1=0.075, \mathrm{wR} 2=0.162$; largest diff. peak and hole: 0.170 and -0.190 e $\AA-3$. 
CCDC-2026782 number contains the supplementary crystallographic data for this structure (2a). These data are provided free of charge via the joint CCDC/FIZ Karlsruhe deposition service, www.ccdc.cam.ac.uk/structures.

\subsection{Syntheses procedures for the preparation of dyes and characterization}

Method A - Microwave irradiation procedure.

Compound 1 (1.00 mmol) and appropriate aldehyde $(1.00 \mathrm{mmol})$ were dissolved in $10 \mathrm{~mL}$ ethanol. A few drops of piperidine as a catalyst was added. The mixture was heated under MWI $(300 \mathrm{~W})$ for $5 \mathrm{~min}$. The reaction mixture was then cooled to room temperature, and the precipitated solid was filtered and washed with ethanol.

Method B - Conventional procedure.

Compound $1(1.00 \mathrm{mmol})$ and appropriate aldehyde $(1.00 \mathrm{mmol})$ were dissolved in cyclohexane (10 ml). A few drops of piperidine were added under stirring. After adding piperidine, and the reaction mixture becomes reddish. After refluxing for $3-4 \mathrm{~h}$, The reaction mixture was then cooled to room temperature, and the precipitated solid was filtered and recrystallized from ethanol.

Method C - Microwave irradiation procedure. 
Corresponding compound $2(1.00 \mathrm{mmol})$ and malononitrile $(1.50 \mathrm{mmol})$ were dissolved in acetonitrile $(10 \mathrm{~mL})$. Pyrrolidine $(1.20 \mathrm{mmol})$ as a catalyst was slowly added. The mixture was heated under MWI ( $300 \mathrm{~W})$ to $78^{\circ} \mathrm{C}$ for $5 \mathrm{~min}$. The reaction mixture was then cooled to room temperature and the precipitated solid was filtered and washed with ethanol.

Method D - Conventional procedure.

The corresponding compound $2(1.00 \mathrm{mmol})$ and malononitrile $(1.50 \mathrm{mmol})$ were dissolved in acetonitrile $(10 \mathrm{ml})$. Pyrrolidine $(1.20 \mathrm{mmol})$ as a catalyst was slowly added. The solution was stirred for $45 \mathrm{~min}$ at room temperature. The precipitated solid was filtered and washed with ethanol.

Method E - Microwave irradiation one-pot procedure.

Compound $1(1.00 \mathrm{mmol})$, appropriate aldehyde $(1.50 \mathrm{mmol})$ and malononitrile $(1.50 \mathrm{mmol})$ were dissolved in $(15 \mathrm{~mL})$ acetonitrile. Pyrrolidine $(1.20 \mathrm{mmol})$ as a catalyst was slowly added. The mixture was heated under MWI $(300 \mathrm{~W})$ to $78^{\circ} \mathrm{C}$ for $5 \mathrm{~min}$. Then the reaction mixture was cooled to room temperature and the precipitated solid was filtered and washed with ethanol.

Method F - Conventional one-pot procedure.

Compound 1 (1.00 mmol), appropriate aldehyde $(1.50 \mathrm{mmol})$ and malononitrile $(1.50 \mathrm{mmol})$ were dissolved in acetonitrile. Pyrrolidine $(1.20 \mathrm{mmol})$ as a catalyst was slowly added. The solution was stirred for $45 \mathrm{~min}$ at room temperature. The precipitated solid was filtered and washed with ethanol. 
(E)-2-(2-benzylidene-2,3-dihydro-1H-inden-1-ylidene)malononitrile (2a): Obtaine d according to Method B, Yield: $97 \%$ (260 mg), yellow solid m.p.: $180-182{ }^{\circ} \mathrm{C}$ (lit. m.p.: 175 - $177{ }^{\circ} \mathrm{C}$ ) [20] FT-IR (Attenuated total reflectance (ATR), $\mathrm{cm}^{-1}$ ): 3061 (C-H Aromatic), 2940 (C H Aliphatic), 2328 (C=N), 1616 (C=C), ${ }^{1} \mathrm{H}$ NMR (600 MHz, DMSO-d6, $\delta$ ppm) $8.40(\mathrm{~d}, J=8.1 \mathrm{~Hz}, 1 \mathrm{H}), 8.20(\mathrm{~s}, 1 \mathrm{H}), 7.74-7.70(\mathrm{~m}, 3 \mathrm{H}), 7.67(\mathrm{~d}$, $J=7.6 \mathrm{~Hz}, 1 \mathrm{H}), 7.60-7.53(\mathrm{~m}, 3 \mathrm{H}), 7.53-7.49(\mathrm{~m}, 1 \mathrm{H}), 4.15(\mathrm{~s}, 2 \mathrm{H}),{ }^{13} \mathrm{C}$ NMR $(151$ MHz, DMSO-d6, $\delta$ ppm) 167.5, 148.4, 137.5, 136.3, 134.9, 134.7, 130.7, 130.4, 129.2, 128.2, 126.1, 124.8, 115.4, 115.0, 36.8. HRMS m/z calculated for $\mathrm{C}_{19} \mathrm{H}_{13} \mathrm{~N}_{2}$ : 269.1079, found $269.1071(\mathrm{M}+\mathrm{H})^{+}$.

(E)-2-(2-(anthracen-9-ylmethylene)-2,3-dihydro-1 $H$-inden-1 -ylidene)malononitrile (2b): Obtained according to Method B, Yield: $43 \%$ (158 mg), Orange solid, m.p.: 253 - $254{ }^{\circ} \mathrm{C}$, FT-IR (ATR, cm¹): 3043 (C-H Aromatic), 2962 (C-H Aliphatic), 2327 (C=N), $1603(\mathrm{C}=\mathrm{C}),{ }^{1} \mathrm{H}$ NMR (600 MHz, DMSO- $\left.d_{6}, \delta \mathrm{ppm}\right) 8.95(\mathrm{~d}, J=0.8 \mathrm{~Hz}, 1 \mathrm{H}), 8.76(\mathrm{~s}$, 1H), $8.45(\mathrm{~d}, J=8.2 \mathrm{~Hz}, 1 \mathrm{H}), 8.28-8.10(\mathrm{~m}, 4 \mathrm{H}), 7.64(\mathrm{dd}, J=11.5,4.1 \mathrm{~Hz}, 1 \mathrm{H}), 7.62$ $-7.55(\mathrm{~m}, 5 \mathrm{H}), 7.41(\mathrm{~d}, J=7.6 \mathrm{~Hz}, 1 \mathrm{H}), 3.34(\mathrm{~s}, 2 \mathrm{H}),{ }^{13} \mathrm{C} \mathrm{NMR}\left(151 \mathrm{MHz}, \mathrm{DMSO}-d_{6}\right.$, $\delta \mathrm{ppm}) 165.5,147.7,142.5,136.3,134.9,133.8,130.9,129.0,128.8,128.6,128.4,128.2$, 127.0, 126.1, 125.8, 125.4, 124.9, 114.9, 108.9, 70.1, 36.1, HRMS m/z calculated for $\mathrm{C}_{27} \mathrm{H}_{17} \mathrm{~N}_{2}$ : 369.1392, found $369.1388(\mathrm{M}+\mathrm{H})^{+}$. 


\section{(E)-2-(2-(pyren-1-ylmethylene)-2,3-dihydro-1 $H$-inden-1-ylide ne)malononitrile}

(2c):

Obtained according to Method B, Yield: $52 \%$ (204 mg), purple solid, m.p.: $280-281^{\circ} \mathrm{C}$, FT-IR (ATR, cm-1): 3038 (C-H Aromatic), 2961 (C-H Aliphatic), 2327 (C=N), 1601 $(\mathrm{C}=\mathrm{C}),{ }^{1} \mathrm{H}$ NMR (600 MHz, DMSO-d6, $\left.\delta \mathrm{ppm}\right) 9.24(\mathrm{~s}, 1 \mathrm{H}), 8.60(\mathrm{~d}, J=9.5 \mathrm{~Hz}, 1 \mathrm{H})$, $8.52(\mathrm{~d}, J=8.2 \mathrm{~Hz}, 1 \mathrm{H}), 8.47(\mathrm{~d}, J=8.8 \mathrm{~Hz}, 1 \mathrm{H}), 8.44(\mathrm{~d}, J=8.5 \mathrm{~Hz}, 1 \mathrm{H}), 8.43-8.37$ $(\mathrm{m}, 3 \mathrm{H}), 8.33(\mathrm{~d}, J=9.3 \mathrm{~Hz}, 1 \mathrm{H}), 8.29(\mathrm{~d}, J=8.2 \mathrm{~Hz}, 1 \mathrm{H}), 8.16(\mathrm{t}, J=7.6 \mathrm{~Hz}, 1 \mathrm{H}), 7.72$ $(\mathrm{t}, J=7.2 \mathrm{~Hz}, 1 \mathrm{H}), 7.66(\mathrm{~d}, J=8.0 \mathrm{~Hz}, 1 \mathrm{H}), 7.61(\mathrm{t}, J=7.7 \mathrm{~Hz}, 1 \mathrm{H}), 3.86(\mathrm{~s}, 2 \mathrm{H}) .{ }^{1} \mathrm{H}$ NMR (600 MHz, $\left.\mathrm{CDCl}_{3}, \delta \mathrm{ppm}\right) \delta 9.34(\mathrm{~s}, 1 \mathrm{H}), 8.66(\mathrm{~d}, J=7.6 \mathrm{~Hz}, 1 \mathrm{H}), 8.39(\mathrm{~d}, J=$ $9.0 \mathrm{~Hz}, 1 \mathrm{H}), 8.29-8.21(\mathrm{~m}, 5 \mathrm{H}), 8.18(\mathrm{~d}, J=8.7 \mathrm{~Hz}, 1 \mathrm{H}), 8.11(\mathrm{~d}, J=8.6 \mathrm{~Hz}, 1 \mathrm{H}), 8.07$ $(\mathrm{t}, J=7.6 \mathrm{~Hz}, 1 \mathrm{H}), 7.58(\mathrm{t}, J=7.3 \mathrm{~Hz}, 1 \mathrm{H}), 7.48(\mathrm{t}, J=8.0 \mathrm{~Hz}, 1 \mathrm{H}), 7.44(\mathrm{~d}, J=7.1 \mathrm{~Hz}$, 1H), 4.05 (s, 2H). ${ }^{13} \mathrm{C}$ NMR (151 MHz, $\left.\mathrm{CDCl}_{3}, \delta \mathrm{ppm}\right) 147.8,138.7,136.9,135.4,135.4$, $134.7,134.6,134.5,132.8,131.3,131.0,130.5,129.9,129.3,129.3,128.4,127.6,127.4$, $126.9,126.7,126.5,126.4,126.4,125.5,124.9,124.7,123.3,118.7,37.4$. HRMS m/z calculated for $\mathrm{C}_{29} \mathrm{H}_{17} \mathrm{~N}_{2}$ : 393.1392, found $393.1384(\mathrm{M}+\mathrm{H})^{+}$.

3-amino-2,4-dicyano-1-phenyl-9H-fluorene (3a): Obtained according to Method F, the compound was purified by column chromatograph. Yield: $41 \%$ (126 mg), grass solid m.p.: 299 - $300{ }^{\circ} \mathrm{C}$ (lit. m.p.: 303 - $\left.305{ }^{\circ} \mathrm{C}\right)$ [34], FT-IR (ATR, cm-1): $3472(\mathrm{~N}-\mathrm{H}), 3376(\mathrm{~N}-\mathrm{H}), 3055(\mathrm{C}-$ H Aromatic), 2986 (C-H Aliphatic), 2328 (C=N), 1628(C=C), ${ }^{1} \mathrm{H}$ NMR (600 MHz, DMSO-d6, $\delta \mathrm{ppm}) 8.37-8.31(\mathrm{~m}, 1 \mathrm{H}), 7.62(\mathrm{dt}, J=6.4,2.3 \mathrm{~Hz}, 1 \mathrm{H}), 7.59-7.56(\mathrm{~m}, 4 \mathrm{H}), 7.56-7.52(\mathrm{~m}$, 2H), $7.50(\mathrm{td}, J=7.3,1.4 \mathrm{~Hz}, 1 \mathrm{H}), 6.72(\mathrm{~s}, 2 \mathrm{H}), 3.68(\mathrm{~s}, 2 \mathrm{H}),{ }^{13} \mathrm{C}$ NMR $\left(151 \mathrm{MHz}, \mathrm{DMSO}-d_{6}\right.$, $\delta$ ppm) 153.5, 146.7, 146.5, 146.3, 137.6, 136.4, 130.4, 129.8, 129.1, 128.7, 128.6, 127.4, 125.6, 121.9, 116.3, 115.9, 94.4, 87.2, 35.3, HRMS m/z calculated for $\mathrm{C}_{21} \mathrm{H}_{14} \mathrm{~N}_{3}$ : 308.1188, found $308.1175(\mathrm{M}-\mathrm{H})^{+}$. 
3-amino-2,4-dicyano-1-(anthracen-9-yl)-9H-fluorene (3b): Obtained according to Method F, the compound was purified by column chromatography. Yield: $32 \%$ (130 mg), grass solid m.p.: $367-368{ }^{\circ} \mathrm{C}$, FT-IR (ATR, cm-1): $3470(\mathrm{~N}-\mathrm{H}), 3362(\mathrm{~N}-\mathrm{H}), 3048(\mathrm{C}-\mathrm{H}$ Aromatic), 2929 (C-H Aliphatic), $2328(\mathrm{C}=\mathrm{N}), 1632$ (C=C), ${ }^{1} \mathrm{H}$ NMR (300 MHz, $\mathrm{CDCl}_{3}, \delta$ ppm) $\delta 8.64(\mathrm{~s}, 1 \mathrm{H}), 8.55(\mathrm{~d}, J=7.8 \mathrm{~Hz}, 1 \mathrm{H}), 8.12(\mathrm{~d}, J=8.4 \mathrm{~Hz}, 2 \mathrm{H}), 7.53(\mathrm{~d}, J=1.4 \mathrm{~Hz}, 1 \mathrm{H})$, $7.50(\mathrm{~d}, J=8.3 \mathrm{~Hz}, 4 \mathrm{H}), 7.46(\mathrm{~d}, J=0.5 \mathrm{~Hz}, 2 \mathrm{H}), 7.44-7.37(\mathrm{~m}, 3 \mathrm{H}), 7.32(\mathrm{~d}, J=7.7 \mathrm{~Hz}, 1 \mathrm{H})$, 5.35 (s, 2H), 3.27 (s, 2H), ${ }^{13} \mathrm{C}$ NMR (151 MHz, DMSO- $\left.d_{6}, \delta \mathrm{ppm}\right) 153.7,147.1,145.8,143.7$, $137.8,132.1,130.9,129.9,129.9,128.8,128.5,128.4,127.6,127.2,125.8,125.7,124.7,122.1$, 115.9, 115.8, 96.5, 88.3, 34.8, HRMS m/z calculated for $\mathrm{C}_{29} \mathrm{H}_{18} \mathrm{~N}_{3}: 408.1501$, found 408.1494 $(\mathrm{M}-\mathrm{H})^{+}$.

3-amino-2,4-dicyano-1-(pyren-1-yl)-9H-fluorene (3c): Obtained according to Method F, the compound was purified by column chromatograph. Yield: $30 \%(129 \mathrm{mg})$, dark green solid m.p.: 327 - $328{ }^{\circ} \mathrm{C}$, FT-IR (ATR, cm-1): 3493 (N-H), 3392 (N-H), 3040 (C-H Aromatic), 2896 (C-H Aliphatic), $2211(\mathrm{C}=\mathrm{N}), 1614(\mathrm{C}=\mathrm{C}),{ }^{1} \mathrm{H}$ NMR (600 MHz, DMSO- $d_{6}, \delta$ ppm) 8.48 $(\mathrm{d}, J=7.8 \mathrm{~Hz}, 1 \mathrm{H}), 8.42(\mathrm{t}, \mathrm{J}=8.4 \mathrm{~Hz}, 2 \mathrm{H}), 8.35(\mathrm{~d}, \mathrm{~J}=7.7 \mathrm{~Hz}, 1 \mathrm{H}), 8.32(\mathrm{dd}, \mathrm{J}=8.1,4.7 \mathrm{~Hz}$, $2 \mathrm{H}), 8.21-8.17(\mathrm{~m}, 1 \mathrm{H}), 8.14(\mathrm{ddd}, J=14.1,7.6,1.0 \mathrm{~Hz}, 2 \mathrm{H}), 7.75(\mathrm{~d}, J=9.2 \mathrm{~Hz}, 1 \mathrm{H}), 7.56$ (tt, $J=6.9,3.3 \mathrm{~Hz}, 1 \mathrm{H}), 7.53-7.45(\mathrm{~m}, 2 \mathrm{H}), 6.89$ (s, 2H)., ${ }^{13} \mathrm{C}$ NMR (151 MHz, DMSO- $d_{6}, \delta$ ppm) $153.5,146.8,146.1,145.6,137.8,131.8,131.3,131.3,130.8,130.3,129.8,128.7,128.2$, $127.6,127.5,127.3,126.7,126.6,125.9,125.7,125.0,124.0123 .9,123.8,122.1,120.0,116.1$, 101.1, 95.9, 87.8, 35.2. HRMS m/z calculated for $\mathrm{C}_{31} \mathrm{H}_{18} \mathrm{~N}_{3}: 432.1501$ found $432.1489(\mathrm{M}-\mathrm{H})^{+}$. 


\section{Results and discussion}

\subsection{Synthesis}

Many methods were reported in the literature for the synthesis of fluorene core [35-39]. In these methods, the fluoren-1-yl fragment is only substituted by small groups . Although such compounds can be obtained with good yields, the synthesis of fluore n-1yl with bulky substituent is more challenging. Targeted fluorenes $\mathbf{3}$ were obtained from 1-dicyanomethyleneindane and appropriate aldehydes in two steps using a previously published method (Scheme 1) [35]. In this strategy, 2-arylidene-1dicyanomethyleneindone derivatives $\mathbf{2}$ were isolated and converted to the corresponding fluorene $\mathbf{3}$ in the presence of malononitrile and pyrrolidine as catalyst. Alternatively the fluore ne 3 can be obtained via a one-pot synthetic procedure (Scheme 1) [35]. Therefore, two different synthetic ways can be compared. Moreover, conventional and microwave irradiation (MWI) were used and compared in each cases and the results are presented in Table 1.

As shown in Table 1, the one pot method permit to obtain the fluorine derivatives 3 whatever the nature of the aldehyde. A decrease of the yield is however observed with anthracen-9-yl and pyren-1-yl bulky substituents and MWI does not improve the yield. On the other hand, the sequential synthesis of fluorene $\mathbf{3}$ can be only achieved for $\mathbf{3 a}$ with a phenyl substituent, dicyanomethyleneindones $\mathbf{2 b}$ and $\mathbf{2 c}$ cannot be converted to fluorene $\mathbf{3 b}$ and $\mathbf{3 c}$ respectively. All compounds have been characterized by ${ }^{1} \mathrm{H}$ and ${ }^{13} \mathrm{C}$ nmr, IR spectrometry as was as HRMS. 


\subsection{X-ray crystallography analysis}

The structure of $\{2-[($ anthracen-9-yl)methylidene $]-2,3$-dihydro- $1 H$-inde n-1ylidene propanedinitrile (2b) was characterized by single crystal X-ray diffraction analysis. The suitable crystal for X-ray analys is was obtained by recrystallization of solid with toluene as solvent. The plot shown in Figure 1 confirms the proposed molecular structure, in particular the $E$ stereoisomery of the exocyclic double bond. Compound $\mathbf{2 b}$ crystallized as red prisms and was solved in the monoclinic space group P21/n with four molecules in the unit cell. The structure has cyano and anthracenyl groups linked with the $\mathrm{C}=\mathrm{C}$ double bonds $(\mathrm{C} 17=\mathrm{C} 25,1.360 \AA$, and $\mathrm{C} 15=\mathrm{C} 16,1.319 \AA)$ to the indan core. The average $\mathrm{C} \equiv \mathrm{N}$ bond length is 1.143 (3) $\AA$, and the average $\mathrm{C}-\mathrm{C}$ single bond length is 1.435 (4) $\AA$ in the malononitrile group. The anthracene and indan rings are almost planar. Dihedral angle between these planes is 77.2 degrees. Deviation from the planarity of the molecule is due to significant steric effects and intermolecular interactions. The crystal packing shows (Fig. 1 - Bottom) that molecules are connected by slight $\mathrm{C}-\mathrm{H} \cdots \mathrm{N}$ $[\mathrm{D} \cdots \mathrm{A}=3.28-3.54 \AA]$ interactions. The $\pi-\pi$ stacking interactions between the delocalize $\mathrm{d}$ $\pi$-electrons of the anthracenyl and indanyl groups are relatively weak. The distance between the ring centroids is in the range of $3.69-5.43 \AA$.

\subsection{Thermal stability}

The thermal stabilities of the compounds were analysed using TGA. It was found that fluorene derivatives 3 were thermally more stable than their 1-dicyanometyleneindane analogues 2 (Table 2) and phenyl derivatives $\mathbf{2 a}$ and $\mathbf{3 a}$ are the less stale in each series. The fact that the compounds do not lose weight up to $100-150{ }^{\circ} \mathrm{C}$ indicates the absence of water or organic 
solvent in the environment. Significantly, $\mathbf{3 b}$ and $\mathbf{3 c}$ compound decomposed at temperatures above $330{ }^{\circ} \mathrm{C}$ and lose $24 \%$ and $29 \%$ of their mass (Figure 2), respectively, indicating that the compounds have the potential to be used in thermally stable and advanced optical fields.

\subsection{Photophysical properties}

The UV/Vis and PL spectra were measured in $\mathrm{CH}_{2} \mathrm{Cl}_{2}$ at room temperature and the data are reported in Table 3. The normalized spectra are displayed in Figures $\mathbf{3}$ and S26. The analyses were carried out using low concentration of chromophores $\left(0.5-1.5 \times 10^{-5} \mathrm{M}\right)$. Except 3a, all compound exhibit various absorption band in UV or blue region of the spectrum. The less energetic absorption band for dicyanometyleneindanes $\mathbf{2}$ is significantly more red-shifted than for fluorene analogues 3. Dicyanometyleneindanes $\mathbf{2}$ are not emissive but fluorenes exhibit purple (3a) or blue (3b and 3c) emission with moderate quantum yield (QY). It should be noted that the QY is significantly higher for the pyren-1-yl derivative $3 \mathbf{c}\left(\Phi_{F}=0.32\right)$ than for the anthracen-9-yl chromophore $3 \mathbf{b}\left(\Phi_{F}=0.09\right)$. According to $\lambda_{\text {onset }}$ values, the HOMO-LUMO gap were estimated to $0.318,0.334$ and 0.338 ev for compounds $\mathbf{3 a}, \mathbf{3 b}$ and $\mathbf{3 c}$. In solid state, only compound 3a significant emission with maxima at 465 and 530 (Figure S27)

The emission properties of compounds $\mathbf{3}$ have been measured in a series of solvents of increasing polarity (Table 4, Figures 4, S28 and S29). A positive emission solvatochromic is globally observed which is characteristic of compounds presenting intramolecular charge 
transfer [40-42]. As expected, the solvatochromic range is more extended for anthracen-9-yl and pyren-1-yl derivatives $\mathbf{3 b}$ and $\mathbf{3} \mathbf{c}$ due to more extended $\pi$-conjugated structure. The Stokes shifts have been plotted versus the solvent polarity function for compounds 3a-c. (Lippert Mataga plot, Figure S30) [43-45]. The slope of the regression lines provide estimation of the increase in dipole moment in the fluorescence state compared to the ground state of ca. 19.1, 22.3 and 21.6 D for $\mathbf{3 a}, \mathbf{3 b}$ and $\mathbf{3 c}$ respectively [46].

In order to study the effect of aggregation on the PL properties of compounds $\mathbf{3}$, their emission spectra were recorded in THF-water mixtures of different ratio, the spectra are displayed in Figures 5, 6 and S29. None of the chromophores exhibits aggregation induced emission (AIE) but the behavior of compound $\mathbf{3 a}$ is different to what is observed for compounds $\mathbf{3 b}$ and $\mathbf{3 c}$. For compound 3a, the addition of water (up to $80 \%$ ) leads to an increase of emission intensity with a slight red-shift of emission maximum (from 428 to $436 \mathrm{~nm}$ ) attributed to an increase of the polarity of the media. For higher ratio of water, the intensity of this emission band significantly decreases and a second emission band of low intensity centerered at $535 \mathrm{~nm}$ appears that may be attributed to the formation of $\mathrm{J}$-aggegates. This leads to turquoise emission for 10:90 THF/water ratio where both bands have similar intensity and green emission for 3:97 THF/water ratio where the first band is almost fully quenched. The behavior of compound $\mathbf{3 b}$ and $\mathbf{3 c}$ is different. In pure THF, compound $\mathbf{3 b}$ exhibits an emission maxima at $447 \mathrm{~nm}$. Between $50 \%$ and $70 \%$ of water a new emission band moving from 499 to $512 \mathrm{~nm}$ leading to green emission is observed (Figure 6). For higher ratio of water, the emission is fully quenched. Compound 3c exhibits similar behavior (Figure S31).

\section{Conclusions}


Two series of chromophores based on 3-amino-2,4-dicyano-1-aryl-9H-fluorene and 1 dicyanomethylene-2-aryl-indone scaffold were successfully synthesized. The one-pot synthetic route using conventional heating revealed to be the most efficient strategy to obtain fluorene derivatives. X-ray structure of 1-dicyanomethylene-2-anthracen-9-y1indone $\mathbf{2 b}$ confirms the $E$ stereoisomery of the double bond. All fluorene derivatives $\mathbf{3}$ are thermally stable up to $300^{\circ} \mathrm{C}$ and exhibit moderate emission properties in solution with emission solvatochromism, characteristic of push-pull derivatives, especially for athracen-yl and pyren-1-yl derivatives $\mathbf{3 b}$ and $\mathbf{3 c}$. Fluorenes $\mathbf{3}$ exhibit aggregation quenched emission behaviour but for compound 3a, the emission intensity is slightly enhanced when water is added to a THF solution in the 50:50 to 70:30 water/THF ratio.

\section{Declaration of interests .}

The authors declare that they have no known competing financial interests or personal relationships that could have appeared to influence the work reported in this paper.

\section{Acknowledgements}

This research was supported by The Scientific and Technological Research Council of Turkey (TUBITAK, 113Z704).

\section{CRediT authorship contribution statement}

Mohamed Yahya: Investigation. Deniz Çakmaz: Investigation. Nurgül Sefe roğlu: Software, Writing - Review \& Editing. Sylvain Achelle: Methodology, Writing - original draft - Review 
\& Editing. Estelle Legall: Methodology. Ertan Şahin: Methodology, Writing - original draft

- Review \& Editing. Zeynel Se fe roğlu: Supervision, Writing - Review \& Editing 


\section{References}

[1] J. Liang, L. Li, X. Niu, Z. Yu, Q. Pei, Elastomeric polymer light-emitting devices and displays, Nat. Photonics. 7 (2013) 817-824. https://doi. org/10.1038/nphoton. 2013.242.

[2] D. Liu, T.L. Kelly, Perovskite solar cells with a planar heterojunction structure prepared using room-temperature solution processing techniques, Nat. Photonics. 8 (2014) 133138. https://doi.org/10.1038/nphoton.2013.342.

[3] H. et al Sekitani, T., Nakajima, H., Maeda, tretchable active-matrix organic lightemitting diode display using printable elastic conductors, Nat. Mater. 8 (2009) 494-499.

[4] M. Kaltenbrunner, T. Sekitani, J. Reeder, T. Yokota, K. Kuribara, T. Tokuhara, M. Drack, R. Schwödiauer, I. Graz, S. Bauer-Gogonea, S. Bauer, T. Someya, An ultralightweight design for imperceptible plastic electronics, Nature. 499 (2013) 458-463. https://doi.org/10.1038/nature 12314.

[5] K.A. Mazzio, C.K. Luscombe, The future of organic photovoltaics, Chem. Soc. Rev. 44 (2015) 78-90. https://doi.org/10.1039/c4cs00227j.

[6] D. Li, H. Zhang, Y. Wang, Four-coordinate organoboron compounds for organic lightemitting diodes (OLEDs), Chem. Soc. Rev. 42 (2013) 8416-8433. https://doi.org/10.1039/c3cs60170f.

[7] P. Gao, M. Grätzel, M.K. Nazeeruddin, Organohalide lead perovskites for photovoltaic $\begin{array}{llllll}\text { applications, } & \text { Energy } & \text { Environ. } & \text { Sci. } & 7 & \text { (2014) }\end{array}$ https://doi.org/10.1039/c4ee00942h.

[8] G. Zhang, X.K. Chen, J. Xiao, P.C.Y. Chow, M. Ren, G. Kupgan, X. Jiao, C.C.S. Chan, X. Du, R. Xia, Z. Chen, J. Yuan, Y. Zhang, S. Zhang, Y. Liu, Y. Zou, H. Yan, K.S. Wong, V. Coropceanu, N. Li, C.J. Brabec, J.L. Bredas, H.L. Yip, Y. Cao, Delocalization of exciton and electron wavefunction in non-fullerene acceptor molecules enables 
efficient organic solar cells, Nat. Commun. 11 (2020) 1-10. https://doi.org/10.1038/s41467-020-17867-1.

[9] D. Sun, D. Meng, Y. Cai, B. Fan, Y. Li, W. Jiang, L. Huo, Y. Sun, Z. Wang, NonFullerene-Acceptor-Based Bulk-Heterojunction Organic Solar Cells with Efficiency over 7\%, J. Am. Chem. Soc. 137 (2015) 11156-11162. https://doi.org/10.1021/jacs.5b06414.

[10] C.D. Andrade, C.O. Yanez, L. Rodriguez, K.D. Belfield, A Series of Fluorene-Based Two-Photon Absorbing Molecules: Synthesis, Linear and Nonlinear Characterization, and Bioimaging, J. Org. Chem. $75 \quad$ (2010) 3975-3982. https://oi.org/10.1021/jo1005075.

[11] U. Scherf, E.J.W. List, Semiconducting polyfluorenes - Towards reliable structureproperty relationships, Adv. Mater. 14 (2002) 477-487. https://doi.org/10.1002/15214095(20020404)14:7<477::AID-ADMA477>3.0.CO;2-9.

[12] M. Knaapila, A.P. Monkman, Methods for controlling structure and photophysical properties in polyfluorene solutions and gels, Adv. Mater. 25 (2013) 1090-1108. https://doi.org/10.1002/adma.201204296.

[13] E. Kozma, W. Mróz, A. Andicsová Eckstein, V. Lukeš, F. Galeotti, A. Šišková, M. Danko, M. Catellani, A joint experimental and theoretical study on the electro-optical properties of 1,6- and 1,7-fluorenyl disubstituted perylene diimide isomers, New J. Chem. 42 (2018) 1061-1066. https://doi.org/10.1039/c 7nj03860g.

[14] G. Ma, H. Zhao, J. Wang, Y. Le, H. Jiang, H. Deng, J. Hao, W. Wan, Studies of fluorine auxochrome in C9-fluorenyl anthracenes on optoelectronic property for blue electroluminescent materials, Dye. Pigment. $158 \quad$ (2018) 420-427. https://doi.org/10.1016/j.dyepig. 2018.06.008.

[15] P. Savel, H. Akdas-Kilig, J.P. Malval, A. Spangenberg, T. Roisnel, J.L. Fillaut, Metal- 
induced dimensionality tuning in a series of bipyrimidine-based ligands: A tool to enhance two-photon absorption, J. Mater. Chem. C. 2 (2014) 295-305. https://doi.org/10.1039/c3tc31370k.

[16] C. Denneval, O. Moldovan, C. Baudequin, S. Achelle, P. Baldeck, N. Plé, M. Darabantu, Y. Ramondenc, Synthesis and Photophysical Properties of Push-Pull Structures Incorporating Diazines as Attracting Part with a Fluorene Core, European J. Org. Chem. 2013 (2013) 5591-5602. https://doi.org/10.1002/ejoc.201300458.

[17] C. Sagan, Y. Jiang, F. Caban, J. Snaider, R. Amell, S. Wei, G.M. Florio, Oligofluorene Molecular Wires: Synthesis and Single-Molecule Conductance, J. Phys. Chem. C. 121 (2017) 24945-24953. https://doi.org/10.1021/acs.jpcc.7b07713.

[18] X. Zhang, S. Ben Hassine, N. Richy, O. Mongin, M. Blanchard-Desce, F. Paul, C.O. Paul-Roth, New porphyrin dendrimers with fluorenyl-based connectors: a simple way to improving the optical properties over dendrimers featuring 1,3,5-phenylene connectors, New J. Chem. 44 (2020) 4144-4157. https://doi.org/10.1039/c9nj06166e.

[19] N.I. Nijegorodov, W.S. Downey, The Influence of Planarity and Rigidity on the Absorption and Fluorescence Parameters and Intersystem Crossing Rate Constant in Aromatic Molecules, 1994. https://pubs.acs.org/sharingguidelines (accessed November $12,2020)$.

[20] S. Tao, Z. Peng, X. Zhang, P. Wang, C.S. Lee, S.T. Lee, Highly efficient non-doped blue organic light-emitting diodes based on fluorene derivatives with high thermal stability, Adv. Funct. Mater. 15 (2005) 1716-1721. https://doi.org/10.1002/adfm. 200500067.

[21] T.M. Figueira-Duarte, K. Müllen, Pyrene-based materials for organic electronics, Chem. Rev. 111 (2011) 7260-7314. https://doi.org/10.1021/cr100428a.

[22] S.W. Yang, A. Elangovan, K.C. Hwang, T.I. Ho, Electronic polarization reversal and excited state intramolecular charge transfer in donor/acceptor ethynylpyrenes, J. Phys. 
Chem. B. 109 (2005) 16628-16635. https://doi.org/10.1021/jp052086u.

[23] Y. Ge, Y. Wen, H. Liu, T. Lu, Y. Yu, X. Zhang, B. Li, S.T. Zhang, W. Li, B. Yang, A key stacking factor for the effective formation of pyrene excimer in crystals: degree of $\pi-\pi$ overlap, J. Mater. Chem. C. $8 \quad$ (2020) 11830-11838. https://doi.org/10.1039/d0tc02562c.

[24] J. Wang, X. Zhang, H.B. Liu, Highly sensitive pyrene-dansyl conjugate-based fluorescent sensor for discriminative detection of water in organic solvents, Dye. Pigment. 182 (2020) 108685. https://doi.org/10.1016/j.dyepig.2020.108685.

[25] M.-H. Ho, B. Balaganesan, C.H.F. Chen, Blue Fluorescence and Bipolar Transport Materials Based on Anthracene and Their Application in OLEDs, Isr. J. Chem. 52 (2012) 484-495. https://doi.org/10.1002/ijch.201100112.

[26] F. Qiu, D. Fang, J. Bai, T. Zhang, Y. Zhu, J. Miao, I. Murtaza, Z. Hu, C. Yan, H. Meng, Anthracene derivatives as highly efficient deep-blue emitters with extremely low driving $\begin{array}{lllllll}\text { voltages, } & \text { Von } \leq 2.7 \quad \mathrm{~V}, & \text { Dye. } & \text { Pigment. } & 180 & (2020) & 108458\end{array}$ https://doi.org/10.1016/j.dyepig. 2020.108458.

[27] Y. Wang, W. Liu, S. Ye, Q. Zhang, Y. Duan, R. Guo, L. Wang, Molecular engineering of anthracene-based emitters for highly efficient nondoped deep-blue fluorescent OLEDs, J. Mater. Chem. C. 8 (2020) 9678-9687. https://doi.org/10.1039/d0tc01964j.

[28] W. Wan, H. Du, J. Wang, Y. Le, H. Jiang, H. Chen, S. Zhu, J. Hao, Novel blue luminescent materials for organic light-emitting diodes based on C9-fluorenyl $\begin{array}{lllll}\text { anthracenes, } & \text { Dye. } & \text { Pigment. } & 96 & \text { (2013) }\end{array}$ https://doi.org/10.1016/j.dyepig. 2012.10.013.

[29] X. Feng, J.Y. Hu, X.F. Wei, C. Redshaw, T. Yamato, Influence of substituent position on thermal properties, photoluminescence and morphology of pyrene-fluorene $\begin{array}{llllll}\text { derivatives, } & \text { J. } & \text { Mol. } & \text { Struct. } & 1086 \quad \text { 216-222. }\end{array}$ 
https://doi.org/10.1016/j.molstruc.2015.01.018.

[30] S.M.M. Reddy, P. Dorishetty, G. Augustine, A.P. Deshpande, N. Ayyadurai, G. Shanmugam, A Low-Molecular-Weight Gelator Composed of Pyrene and Fluorene Moieties for Effective Charge Transfer in Supramolecular Ambidextrous Gel, Langmuir. 33 (2017) 13504-13514. https://doi.org/10.1021/acs.langmuir.7b03453.

[31] C. Lavanya Devi, K. Yesudas, N.S. Makarov, V. Jayathirtha Rao, K. Bhanuprakash, J.W. Perry, Fluorenylethynylpyrene derivatives with strong two-photon absorption: Influence of substituents on optical properties, J. Mater. Chem. C. 3 (2015) 3730-3744. https://doi.org/10.1039/c4tc02896a.

[32] H. Usta, W.C. Sheets, M. Denti, G. Generali, R. Capelli, S. Lu, X. Yu, M. Muccini, A. Facchetti, Perfluoroalkyl-functionalized thiazole-thiophene oligomers as N-channel semiconductors in organic field-effect and light-emitting transistors, Chem. Mater. 26 (2014) 6542-6556. https://doi.org/10.1021/cm503203w.

[33] D.F. Eaton, Reference Materials for Fluorescence Measurement, Pure Appl. Chem. 60 (1988) 1107-1114. https://doi.org/10.1351/pac198860071107.

[34] J. Mirek, P. Milart, Differences between the Reaction of 2-Benzylidenecyc lopentan one with Malononitrile and the Reaction of Cyclopentylidenemalononitrile with Aromatic Aldehydes; Synthesis of Strong Fluorescent o-Aminonitriles, 1986.

[35] E. Yalçin, M. Matković, M. Jukić, L.G. Obrovac, I. Piantanida, Z. Seferoğlu, Novel fluorene/fluorenone DNA and RNA binders as efficient non-toxic ds-RNA selective $\begin{array}{llll}\text { fluorescent } & \text { probes, } & \text { Tetrahedron. } & 74 \quad \text { 535-543. }\end{array}$ https://doi.org/10.1016/j.tet.2017.12.008.

[36] L. Rong, H. Han, H. Jiang, S. Tu, Efficient and Facile Synthesis of 3-Amino-1-aryl-9 $H$ -fluorene-2,4-dicarbonitrile Under Solvent-Free Conditions, Synth. Commun. 39 (2009) 3493-3499. https://doi.org/10.1080/00397910902779298. 
[37] X.S. Wang, M.M. Zhang, Q. Li, C.S. Yao, S.J. Tu, An improved and clean procedure for the synthesis of one-donor poly-acceptors systems containing 2,6-dicyanoamine moiety in aqueous media catalyzed by TEBAC in the presence and absence of $\mathrm{K} 2 \mathrm{CO} 3$, Tetrahedron. 63 (2007) 5265-5273. https://doi.org/10.1016/j.tet.2007.03.154.

[38] E. Yalçin, H. Duyar, D. Çakmaz, E. Şahin, Z. Seferoğlu, The synthesis of blue emitting 3-Amino-1-hetarylfluorenes and their unprecedented alkylated derivatives, Tetrahedron. 75 (2019) 130464. https://doi.org/10.1016/j.tet.2019.130464.

[39] Y. Zhou, J. Wang, R. Du, G. Zhang, W. Wang, C. Guo, Microwave-Assisted One-Pot Synthesis of 3-Amino-1-aryl-8-bromo-2,4-dicyano-9 $H$-fluorenes in Water, Synth. Commun. 41 (2011) 3169-3176. https://doi.org/10.1080/00397911.2010.517377.

[40] R. Lartia, C. Allain, G. Bordeau, F. Schmidt, C. Fiorini-Debuisschert, F. Charra, M.P. Teulade-Fichou, Synthetic strategies to derivatizable triphenylamines displaying high two-photon absorption, J. Org. Chem. $73 \quad$ (2008) 1732-1744. https://doi.org/10.1021/jo702002y.

[41] K. Hoffert, R.J. Durand, S. Gauthier, F. Robin-le Guen, S. Achelle, Synthesis and Photophysical Properties of a Series of Pyrazine-Based Push-Pull Chromophores, European J. Org. Chem. 2017 (2017) 523-529. https://doi.org/10.1002/ejoc.201601204.

[42] J. Rodríguez-Aguilar, M. Vidal, C. Pastenes, C. Aliaga, M.C. Rezende, M. Domínguez, The Solvatofluorochromism of 2,4,6-Triarylpyrimidine Derivatives, Photochem. Photobiol. 94 (2018) 1100-1108. https://doi.org/10.1111/php.12982.

[43] N. Mataga, Y. Kaifu, M. Koizumi, Bull. Chem. Soc. Jpn. 28 (1955) 28, 690-691.

[44] N. Mataga, Y. Kaifu, M. Koizumi, Bull. Chem. Soc. Jpn. 29 (1956), 465-470.

[45] E. Lippert, Zeitschrift für Elektrochemie, Berichte der Bunsengesellschaft fûr physikalische Chemie, 61 (1957), 962-975.

[46] G. He, J. Shao, Y. Li, J. Hu, H. Zhu, X. Wang, Q. Guo, C. Chi, A. Xia, Phys. Chem. 
Chem. Phys. 18 (2016) 6789-6798. https://doi.org/10.1039/c5cp07563g.

[47] C. Reichardt, Solvatochromic Dyes as Solvent Polarity Indicators, (n.d.). https://pubs.acs.org/sharingguidelines (accessed November 12, 2020). 


\section{CAPTIONS}

Scheme Captions

Chart 1. Structure of studied compounds.

Scheme 1. Synthetic routes for compounds $2 \mathrm{a}-\mathrm{c}$ and $3 \mathrm{a}-\mathrm{c}$.

\section{Figure Captions}

Figure 1. (Top) Molecular structure of $2 b$ (asymmetric unit). Thermal ellipsoids are drawn at the $40 \%$ probability level. (Bottom) Stacking motif with the unit cell viewed down along the c-axis. Dashed lines indicate $\mathrm{C}-\mathrm{H} \cdots \mathrm{N}$ interactions.

Figure 2. TGA curves of chromophores $\mathbf{2}$ and $\mathbf{3}$ under nitrogen atmosphere in the temperature range of $50-600{ }^{\circ} \mathrm{C}$ at a heating rate of $10{ }^{\circ} \mathrm{C}$ min- 1 .

Figure 3. Normalized absorption (dashed lines)and emission (solid lines) spectra of compounds 3 in $\mathrm{CH} 2 \mathrm{Cl} 2$. Insert: photographs of $\mathrm{CH} 2 \mathrm{Cl} 2$ solution taken in the dark upon irradiation with hand-held UV lamp $(\lambda e m=366 \mathrm{~nm})$.

Figure 4. Normalized emission spectra of compound $3 \mathrm{~b}$ in various solvent $(\lambda e x t=369 \mathrm{~nm})$

Figure 5. Emission spectra of compound 3a in THF/water mixture $(c=1.510-5 \mathrm{M}, \lambda$ ext $=$ $379 \mathrm{~nm}$ ) Insert: photographs of solution with 100:0 10:90 3:97 THF/water ratio taken in the dark upon irradiation with hand-held UV lamp $(\lambda \mathrm{em}=366 \mathrm{~nm})$. 
Figure 6. Emission spectra of compound $\mathbf{3 b}$ in THF/water mixture $(\mathrm{c}=1.510-5 \mathrm{M}$, $\lambda$ ext $=$ $360 \mathrm{~nm}$ ) Insert: photographs of solution with 100:0 50:50 10:90 THF/water ratio taken in the dark upon irradiation with hand-held UV lamp $(\lambda \mathrm{em}=366 \mathrm{~nm})$.

\section{Table Captions}

Table 1. Yields of compounds according to the methods used.

Table 2. Thermal decomposition values (weight loss of 5\%) of compounds 2 and $\mathbf{3}$.

Table 3. UV-Vis and photoluminescence (PL) data of compounds 2 and $\mathbf{3}$ in $\mathrm{CH}_{2} \mathrm{Cl}_{2}$

Table 4. Emission solvatochromism of compounds 3 in various solvents. 


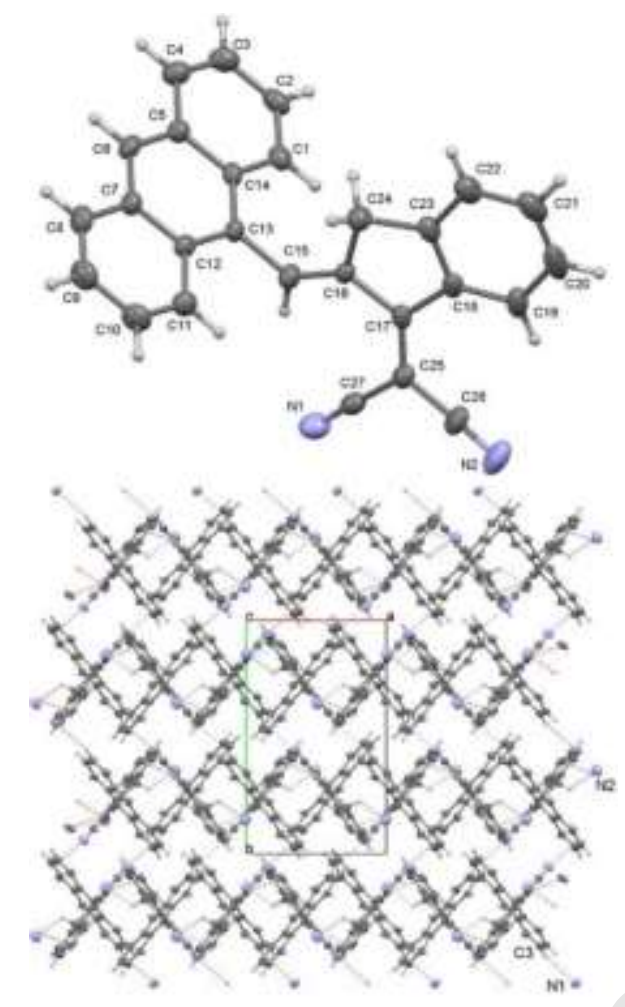

Fig.1. (Top) Molecular structure of $\mathbf{2 b}$ (asymmetric unit). Thermal ellipsoids are drawn at the $40 \%$ probability level. (Bottom) Stacking motif with the unit cell viewed down along the caxis. Dashed lines indicate $\mathrm{C}-\mathrm{H} \cdots \mathrm{N}$ interactions.
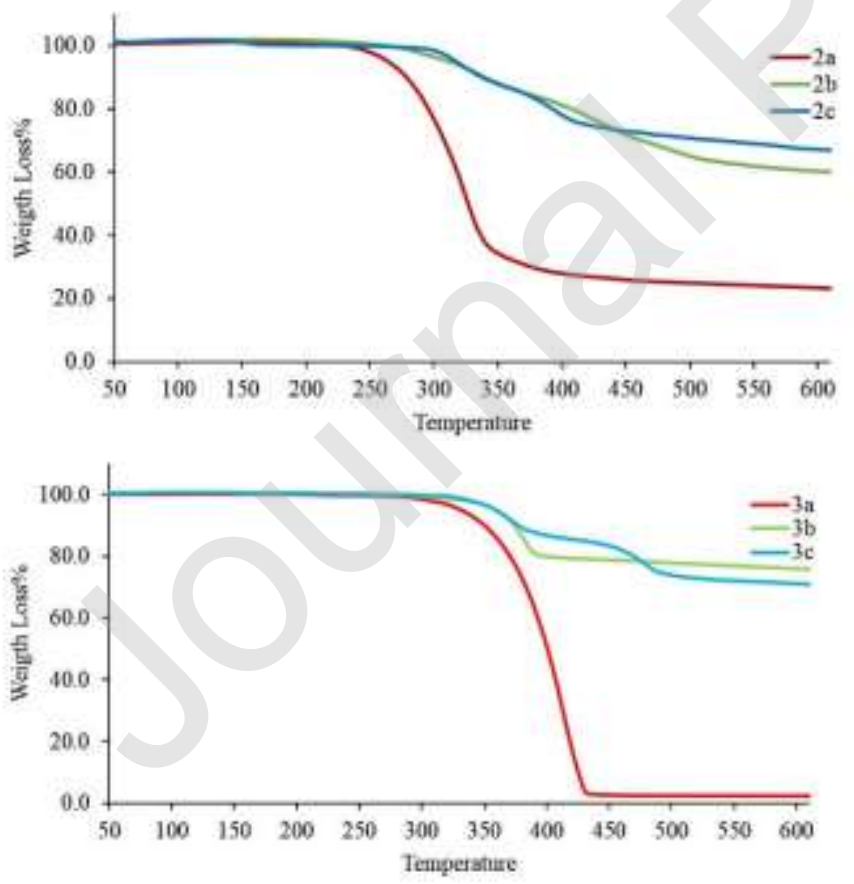
Fig.2. TGA curves of chromophores $\mathbf{2}$ and $\mathbf{3}$ under nitrogen atmosphere in the temperature range of $50-600{ }^{\circ} \mathrm{C}$ at a heating rate of $10{ }^{\circ} \mathrm{C} \mathrm{min}^{-1}$.

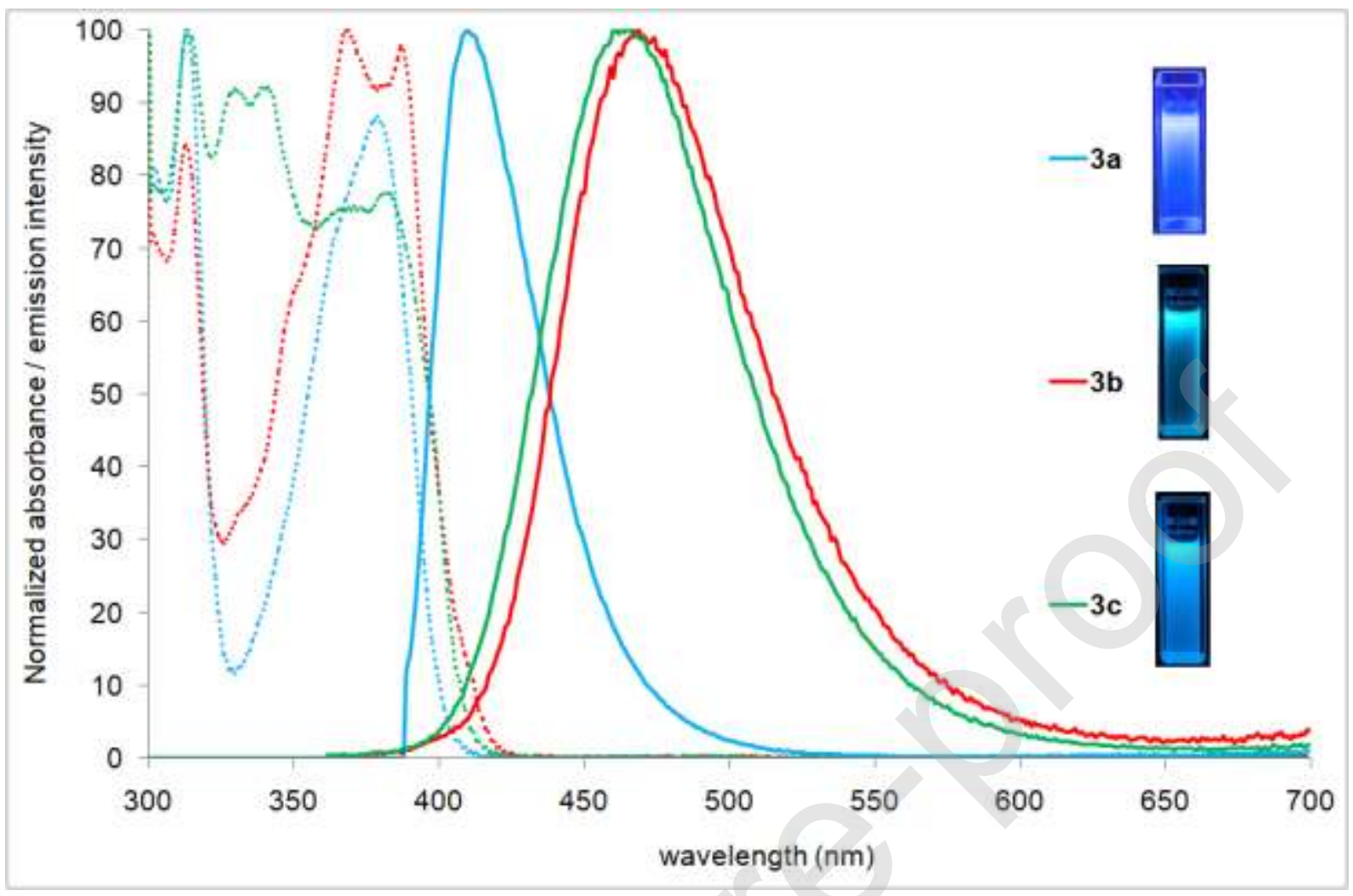

Fig.3. Normalized absorption (dashed lines) and emission (solid lines) spectra of compounds 3 in $\mathrm{CH}_{2} \mathrm{Cl}_{2}$. Insert: photographs of DCM solution taken in the dark upon irradiation with handheld UV lamp ( $\left.\lambda_{e m}=366 \mathrm{~nm}\right)$. 


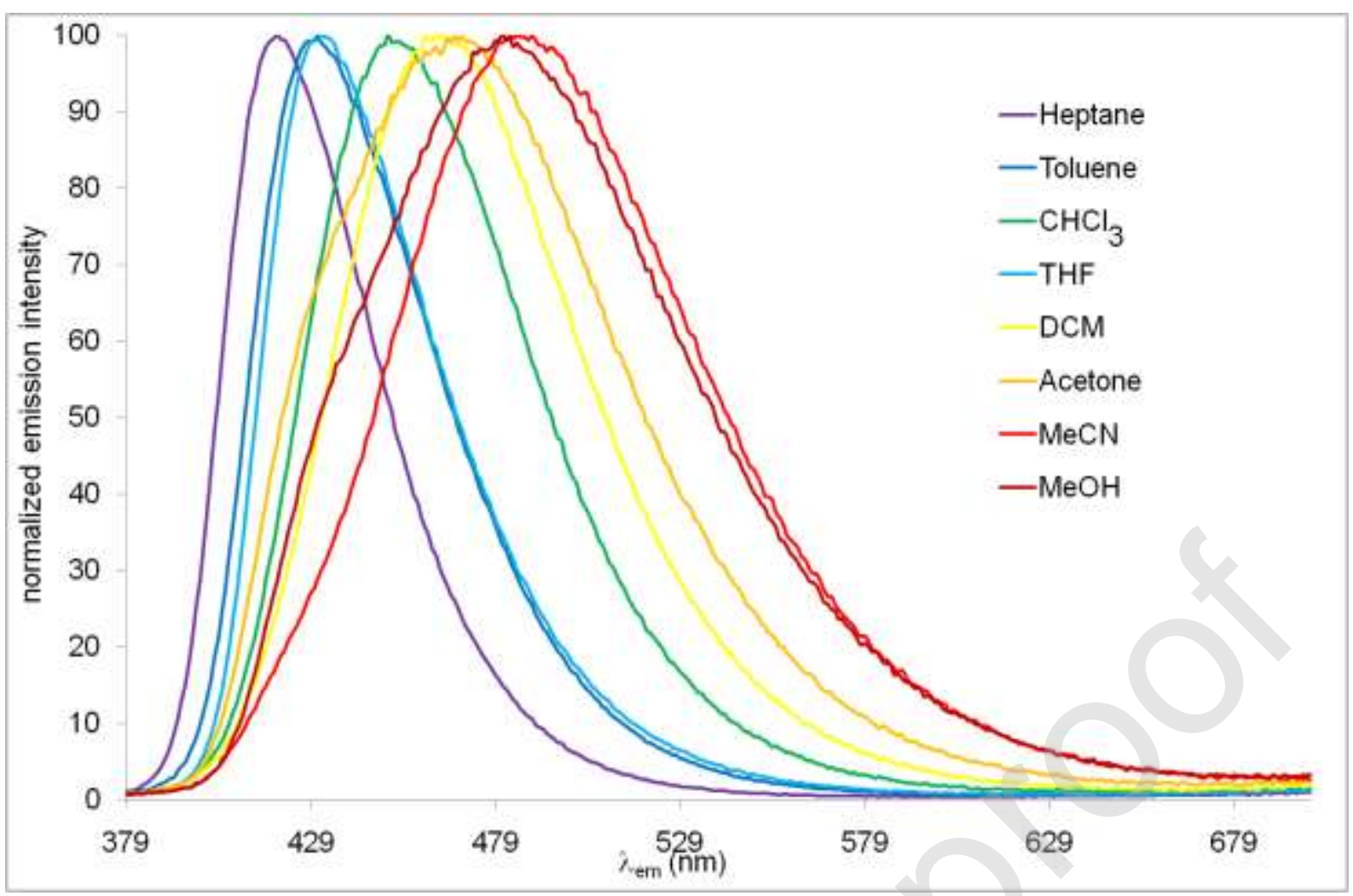

Fig.4. Normalized emission spectra of compound $\mathbf{3 b}$ in various solvent $\left(\lambda_{\text {ext }}=369 \mathrm{~nm}\right)$

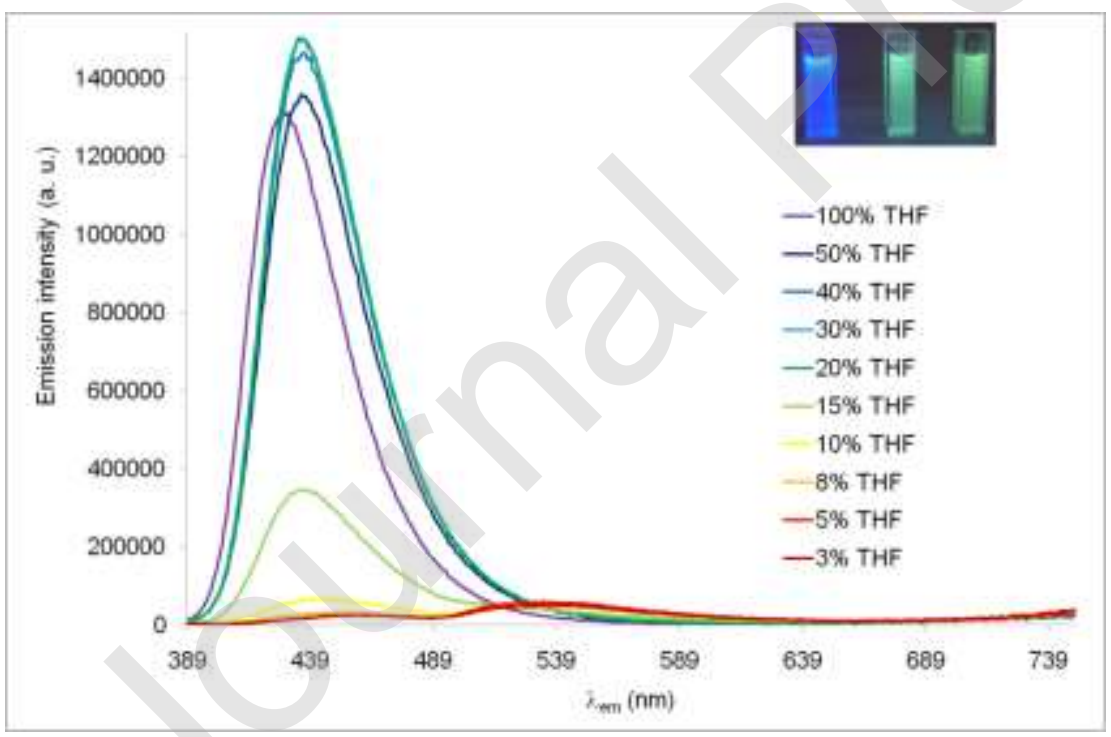

Fig.5. Emission spectra of compound 3a in THF/water mixture $\left(c=1.510^{-5} \mathrm{M}, \lambda_{\text {ext }}=379 \mathrm{~nm}\right)$ Insert: photographs of solution with 100:0 10:90 3:97 THF/water ratio taken in the dark upon irradiation with hand-held UV lamp $\left(\lambda_{e m}=366 \mathrm{~nm}\right)$. 


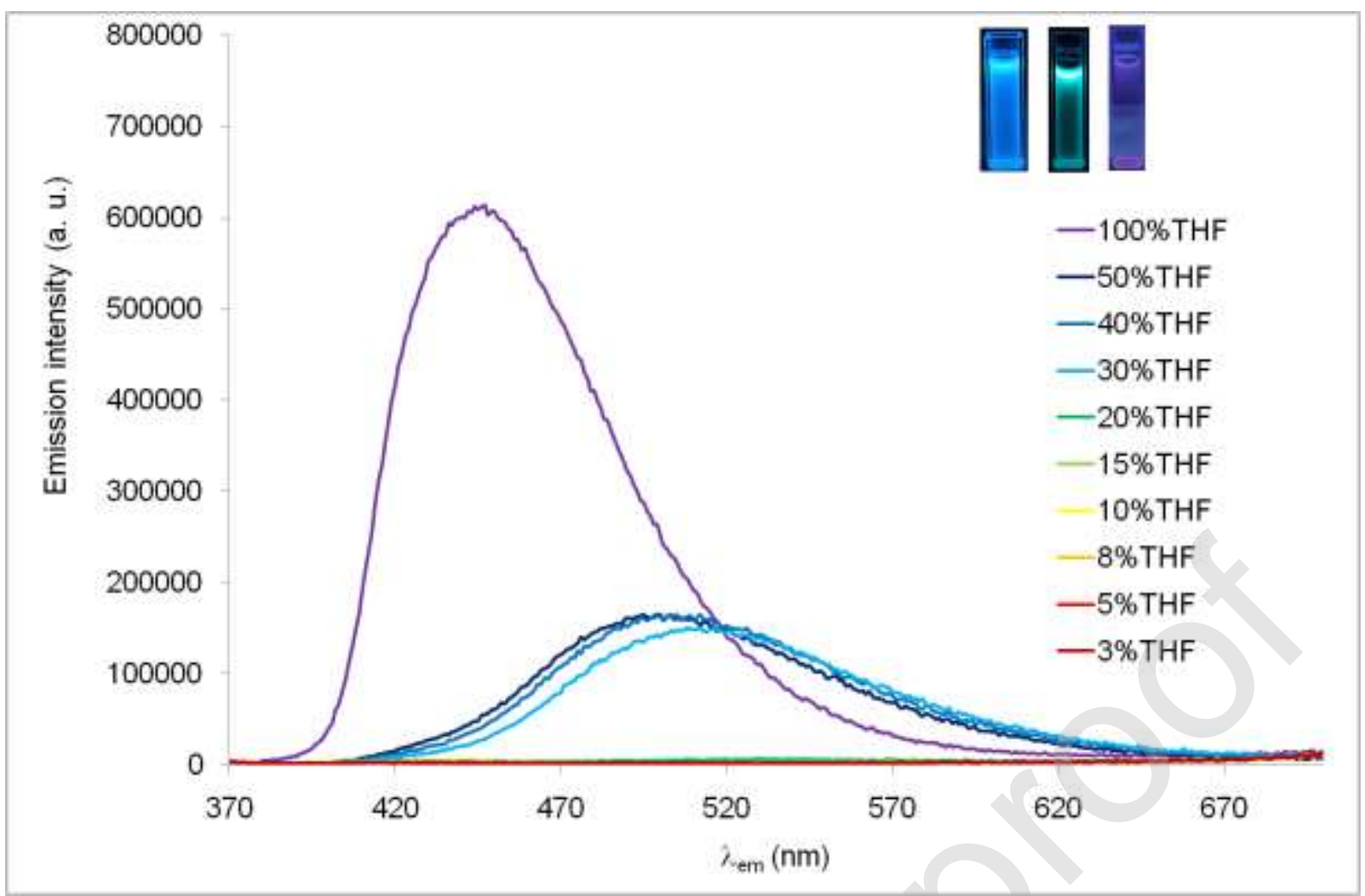

Fig.6. Emission spectra of compound $3 \mathbf{b}$ in THF/water mixture $\left(c=1.510^{-5} \mathrm{M}, \lambda_{\text {ext }}=360 \mathrm{~nm}\right)$ Insert: photographs of solution with 100:0 50:50 10:90 THF/water ratio taken in the dark upon irradiation with hand-held UV lamp $\left(\lambda_{e m}=366 \mathrm{~nm}\right)$. 
<smiles>N#CC(C#N)=C1/C(=C/c2ccccc2)Cc2ccccc21</smiles>

2a<smiles>N#Cc1c(N)c(C#N)c2c(c1-c1ccccc1)Cc1ccccc1-2</smiles>

3a<smiles>N#CC(C#N)=C1/C(=C/c2c3ccccc3cc3ccccc23)Cc2ccccc21</smiles>

$2 \mathbf{b}$<smiles>N#Cc1c(N)c(C#N)c(-c2c3ccccc3cc3ccccc23)c2c1-c1ccccc1C2</smiles><smiles>N#CC(C#N)=C1/C(=C/c2ccc3ccc4cccc5ccc2c3c45)Cc2ccccc21</smiles>

2c

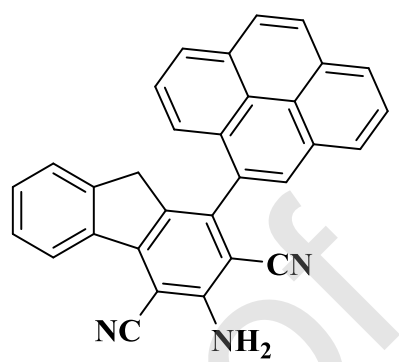

$3 \mathbf{b}$

$3 c$

Chart 1. Structure of studied compounds.<smiles>O=C1CCc2ccccc21</smiles>

Malononitrile, NaAOc EtOH, R.T.<smiles>N#CC(C#N)=C1CCc2ccccc21</smiles>

Method E (MWI-One Pot) Method F (Conventional-One Pot)<smiles>[R]c1c(C#N)c(N)c(C#N)c2c1Cc1ccccc1-2</smiles>

3 a-c<smiles>[R]=C=[V]</smiles>

(a) (b)

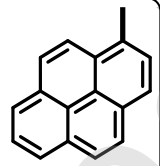

(c)
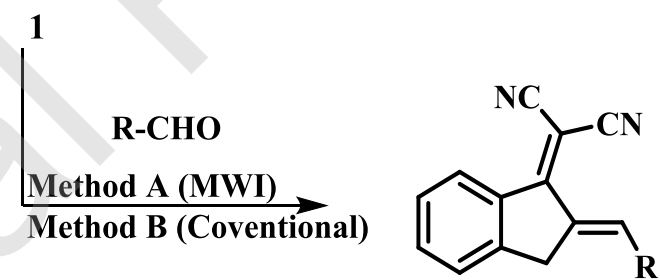

2 a-c

Scheme 1. Synthetic routes for compounds $\mathbf{2 a - c}$ and 3a-c 
Table 1. Yields of compounds according to the methods used.

\begin{tabular}{|c|c|c|c|c|}
\hline Entry & Compound & $\overline{\mathbf{R}}$ & Method & Yield, \% \\
\hline \multirow{2}{*}{1} & \multirow{2}{*}{$2 \mathbf{a}$} & \multirow{2}{*}{ phenyl } & $\bar{A}$ & $-a$ \\
\hline & & & B & 97 \\
\hline \multirow{2}{*}{2} & \multirow{2}{*}{$2 \mathrm{~b}$} & \multirow{2}{*}{ anthracen-9-yl } & A & 43 \\
\hline & & & B & 43 \\
\hline \multirow[t]{2}{*}{3} & \multirow[t]{2}{*}{ 2c } & \multirow{2}{*}{ pyren-1-yl } & A & 52 \\
\hline & & & B & 43 \\
\hline \multirow{4}{*}{4} & \multirow{4}{*}{ 3a } & \multirow{4}{*}{ phenyl } & D & 14 \\
\hline & & & E & 31 \\
\hline & & & $\mathrm{F}$ & 41 \\
\hline & & & $\mathrm{C}$ & $-a$ \\
\hline \multirow[t]{3}{*}{5} & \multirow{3}{*}{ 3b } & \multirow{3}{*}{ anthracen-9-yl } & D & $-\mathrm{a}$ \\
\hline & & & $\mathrm{F}$ & 32 \\
\hline & & & C & - \\
\hline \multirow{2}{*}{6} & \multirow{2}{*}{$3 c$} & \multirow{2}{*}{ pyren-1-yl } & D & $-\mathrm{a}$ \\
\hline & & & $\begin{array}{l}\mathrm{E} \\
\mathrm{F}\end{array}$ & $\begin{array}{l}30 \\
30\end{array}$ \\
\hline
\end{tabular}

${ }^{a}$ compound could not be obtained.

Table 2. Thermal decomposition values (weight loss of 5\%) of compounds 2 and $\mathbf{3}$.

\begin{tabular}{cc}
\hline Compound & Temperature ${ }^{\mathbf{0}} \mathbf{C}$ \\
\hline $\mathbf{2 a}$ & 246 \\
$\mathbf{2 b}$ & 282 \\
$\mathbf{2 c}$ & 299 \\
$\mathbf{3 a}$ & 300 \\
$\mathbf{3 b}$ & 327 \\
$\mathbf{3 c}$ & 334 \\
\hline
\end{tabular}

Table 3. UV-Vis and photoluminescence (PL) data of compounds $\mathbf{2}$ and $\mathbf{3}$ in dichloromethane $(\mathrm{DCM})$

\begin{tabular}{cccccc}
\hline Compound & $\begin{array}{c}\lambda_{\text {abs }} \\
(\mathbf{n m})\end{array}$ & $\begin{array}{c}\boldsymbol{\varepsilon} \\
\left(\mathbf{m M}^{-\mathbf{1}} \mathbf{c m}^{-\mathbf{1}}\right)\end{array}$ & $\begin{array}{c}\lambda_{\mathrm{em}} \\
(\mathbf{n m})\end{array}$ & $\Phi_{F}$ & $\begin{array}{c}\text { Stokes shift } \\
\left(\mathbf{c m}^{-\mathbf{1}}\right)\end{array}$ \\
\hline $\mathbf{2 a}$ & $362 / 390$ & $26.9 / 22.0$ & $-^{\mathrm{a}}$ & $-^{\mathrm{a}}$ & $-^{\mathrm{a}}$ \\
$\mathbf{2 b}$ & $365 / 475$ & $23.7 / 5.3$ & $-^{\mathrm{a}}$ & $-^{\mathrm{a}}$ & $-^{\mathrm{a}}$
\end{tabular}




\begin{tabular}{cccccc}
$\mathbf{2 c}$ & $343 / 487$ & $42.9 / 22.1$ & $-\mathrm{-a}$ & $-\mathrm{a}$ & $-\mathrm{a}$ \\
\hline $\mathbf{3 a}$ & 379 & 10.5 & 410 & 0.32 & 1995 \\
$\mathbf{3 b}$ & $313 / 369 / 387$ & $19.2 / 22.8 / 22.3$ & 467 & 0.09 & 4426 \\
$\mathbf{3 c}$ & $314 / 330 / 341 / 382$ & $31.2 / 28.7 / 28.7 / 24.2$ & 463 & 0.32 & 4580 \\
\hline
\end{tabular}

${ }^{a}$ no emission detected

Table 4. Emission solvatochromism of compounds 3 in various solvents.

\begin{tabular}{lllllllll}
\hline Compds & $\begin{array}{l}n- \\
\text { heptane }\end{array}$ & Toluene & THF & $\mathrm{CHCl}_{3}$ & $\mathrm{DCM}$ & Acetone & $\mathrm{MeCN}$ & $\mathrm{MeOH}$ \\
& $30.9^{[\mathrm{a}]}$ & $33.9^{[\mathrm{a}]}$ & $37.4^{[\mathrm{a}]}$ & $39.1^{[\mathrm{a}]}$ & $40.7^{[\mathrm{a}]}$ & $42.2^{[\mathrm{a}]}$ & $45.6^{[\mathrm{a}]}$ & $55.4^{[\mathrm{a}]}$ \\
\hline 3a & 402 & 416 & 428 & 417 & 410 & 427 & 423 & 433 \\
$\mathbf{3 b}$ & 420 & 443 & 447 & 460 & 467 & 481 & 493 & 496 \\
$\mathbf{3 c}$ & 420 & 431 & 432 & 450 & 463 & 468 & 485 & 481 \\
\hline
\end{tabular}

${ }^{[a]} \mathrm{E}_{\mathrm{T}}(30)$, Dimoth-Reichardt polarity parameter in $\mathrm{kcal} \mathrm{mol}^{-1}$.[47] 